\title{
Communalism as a Theory of Justice and the Human Person in
} African Culture

\author{
Dorothy Oluwagbemi-Jacob \\ University of Calabar
}

\begin{abstract}
Discussions about justice in cross-cultural context give rise to assorted theories. In this paper, issues surrounding communalism as a theory of justice in African culture will be examined with a view to show that its principles of care and fellow feeling could be worked out to address the problem of alienation from society characterizing some members of the contemporary African society. Recognition of the social dynamics of human society and relationships is of essence to communalism. As a theory of justice and a world view, communalism describes the human being as "being with others" and what that should be. The expression, "I am because we are, and because we are, I am" is the driving force of the communalistic society. Such a society is characterized by care, love, belongingness, solidarity, and interconnectedness. The aim of this paper is to highlight the manifestations of the idea of justice in communalism using leadership or governance, consensus in decision making, moral rules, punishment for wrong doing, and the equitable distribution of resources. It also aims to show that the communalist idea of justice is integrationist in outlook being constitutive of political and socio-economic elements, which the individual enjoys in practical terms as opposed to the paper rights, which citizens in much of the contemporary societies enjoy. The paper notes that drastic changes have occurred in the socio-economic relations within African societies as a consequence of acculturation subsequent to European colonization and these have had far reaching consequences.
\end{abstract}

Keywords: Communalism, Africa, justice, culture, human person, solidarity, interconnectedness, colonization

\section{Introduction}

The concept of justice has existed throughout human history but what constitutes its essence does not seem to command a general agreement. It is however, obvious that amidst the disparate viewpoints which have emerged from the justice discourses, its vital role in every age and clime cannot be overemphasized. The reason is that it is the capstone that maintains the social edifice and enables the citizens to maintain the condition of truthfulness and friendship, which is the basis of unforced and fruitful cooperation as well as helps public authority to win the confidence and respect of the people (De Jouvenal 1957, 139). Thus, at the level of the individual's relations with the society or state, justice remains the substratum on which hinges order and peace. It therefore, functions to preserve the status quo or in some cases challenge or overthrow it.

Anyone who doubts the veracity of the above assertion should reflect on the issues, which are thematic to the Niger Delta crisis in Nigeria and the Arab spring that swept through Tunisia, Egypt, Libya, and Syria. In the

Dorothy Oluwagbemi-Jacob, full professor, Department of Philosophy, University of Calabar, Nigeria; main research field: Social and political philosophy and African philosophy. Email: doron32@yahoo.com. 
cases mentioned here, issues organized around the negation of justice (social justice or otherwise) have been implicated.

A normal and average human being inclines to relate with fellow human beings because such is not complete in himself. That is what the Greek philosopher, Aristotle meant when he declared in his Politics that man was a political animal whose nature was to live in the state. Living in the state or society means relating with other humans, transacting business with them, giving to and receiving from them, caring for and being cared for by them, and having a sense of responsibility and obligations toward the commonwealth of which one is a part. In short, these involve shunning the solitary and I am alone kind of existence. It is in this kind of situation that justice issues emerge.

It is germane to affirm at this point that some socio-political or socio-economic systems may frustrate the above natural inclinations of the human person. There are also those that promote them. One of such systems that promote these is that of communalism.

Communalism is a socio-economic as well as a moral framework in which caring, friendship, and genuine concern for others characterize relationships.

The heart of communalism is human sociability. According to Innocent Asouzu (2007), within most traditional African societies, the communal belongingness provides safety nets for the individual's interest to be protected and guaranteed. He makes the point that "human life becomes more dangerous and precarious the further away one goes from one's community, one's own immediate neighborhood, one's own clan, kith, and kin, and from Umunna (children of the same father)" (355).

Chukwuemeka Nze $(1989,8)$ makes a similar point in his view that "communalism in so far as it is a democratic system and in so far as it is a common shelter, under which all members of the extended family operate and are housed, contains the germ of the realization of the individual and his personality. It is the means to avoid sorrows that befall an individual."

The point Asouzu and Nze are making here is that the individual has some measure of security in terms of his welfare within the communalist framework. This calls for the cooperation of community members to band together to forge a common front to face challenges that human existence might bring. This understanding of communalism implies helping one's unfortunate neighbors.

Indeed, some writers regard communalism as an idea that should be universalized as a paradigm for authentic mutual existence between units within a given framework. This is quite a noble ideal which Agbafor Igwe (1992) endorses in his view that the important principles of care and fellow feeling, which are the hallmark of communalism would be worked out to form the basis of a more adequate socio-political philosophy in contemporary Africa. Clearly, for Igwe, the thrust of communalism is, "be your brother's keeper," as well as care and mutual existence. It advocates a basic disposition to altruism, a tendency to consensus, and characteristic philanthropic attitudes (Odimegwu 2007, 7).

Ekei $(2002,2)$ examines justice in the context of communalism and discerns four moments namely, justice as coexistence, justice as acceptance, justice as caring, and justice as concern. He specifically mentions belongingness as an attribute of right, affirming that to associate with others is a demonstration that the associates have mutual expectations of rights and obligations from one another. Just because he belongs, the handicapped and the destitute have their legitimate dues from their community out of moral justice and not out of charity. What this means is that in the communal setting, the seriously deprived have expectations in justice from the community, just as they have rights of acceptance of caring and being cared for and being cherished as 
persons who belong to the same community. The question is: How relevant is the communalist practice today? To what extent can such a practice help to address the problem of alienation of many from the society?

The main objective of this paper is to examine communalism as a theory of justice with a view to show that its principles of care and fellow feeling can be worked out to address the problem of alienation from society characterizing some members of the contemporary African society. The paper highlights the manifestations of the communalistic idea of justice using leadership or governance, consensus in decision making, moral rules, punishment for wrong doing, and the equitable distribution of resources. It argues that the communalistic idea of justice is integrationist in outlook and is inclusive of both political and socio-economic elements of justice, which the individual enjoys in practical terms. The paper however, observes that drastic changes have occurred in the socio-economic relations consequent upon the invasion of colonialism and that these have had far reaching consequences. The Igbo African of south-east Nigeria is used as point of departure.

To accomplish its main objective, this paper is divided into three sections. Section one deals with the praxis of communalism. In section two, efforts are made to show how communalism as a theory of justice manifests in various spheres. Section three discusses the consequences of the dilution of communalistic values for contemporary African society. This section also embodies the conclusion.

\section{Communalism: Praxis}

Communalism is that philosophy of living which affirms that human beings are not self-sufficient but benefit from one another as they share their joy and sorrows among other things. In the communalistic framework, caring, compassion, and generosity constitute the motive for action. It is the hallmark of Igbo African traditional life before European colonization and the consequent disruption of Africa's economic and social life. It is driven by the humanistic principle of living which emphasizes the welfare of the individual, brotherly love, and fellow feeling. The hearts of this socio-economic system are human sociability and group solidarity. Its attraction consists in its demand that needy members of the society should be catered for through the collective charity of those who are more privileged among them.

By reason of this traditional ideology food, a house and a wife (in the case of a man who could not afford to marry by himself) may be jointly provided by family members. The same principle of joint effort for the overall welfare of every individual is the concern of everyone else. One is not indifferent to the plight of the other members of the family or clan (Igwe 1992). Other terms such as Ubuntu and family hood are used by other writers to characterize this way of relating to others in Africa.

At the level of the family, the rich and the successful are expected to share their wealth with poorer relatives; in return, he gains solidarity, security, protection, and services that poor relatives can render (Agbakoba 2012). Also, the sick, the orphans, and the elderly are catered for in the family by the principle of "be your brother's keeper."

At the level of the village/clan/tribe, natural resources are communally owned as opposed to the practice of primitive accumulation by a few. One can still see some of its manifestations in modern times. For instance, in Igboland, palm trees in the village farmlands are not harvested individually even if they are found in one's farmland. When the fruits are ripe for harvesting, the elders meet to decide on a day the community members can go en masse to harvest. This is called iwu nkwu (palm harvesting rule) in Ubakala community of Umuahia in Abia state of Nigeria. Normally, men and women who are interested in harvesting the palm fruits go to contract palm tree climbers from other places to come and cut for them at a fee. Harvesting the palm fruits 
outside the approved time by the elders is frowned at and can attract sanctions from the community. This is just one manifestation of the communalistic life style.

One also finds that in the case of marriage gifts and bride price as this is not a strictly family affair. It is not just the parents of the bride who benefit. Each community has a sharing formula that apportions a part of the gifts to the Umunna and a part to the parents, with the latter having no say in the marriage gift negotiation. Those whose daughters absconded with a man without being properly married and those men who have not gone to properly marry their wives in accordance with the marriage custom of the community are automatically excluded from participating in the sharing of such gifts. Furthermore, such sayings such as otu onye anaghi azu nwa (one person does not bring up a child) are pointers to the communalistic lifestyle, which permits an adult to spank an erring child, whether such a child is biologically one's or not.

At the urban level, the communalist lifestyle finds expression in the non-state regulated and administered associations, which form part of civil society (Wingo 2004, 450-9). They take the form of local government or a town union. Membership to such associations enables persons to form tightly woven networks for both the good of the individual and society at large. These encourage members to identify the issues that affect fellow members, such as lending a helping hand in time of need, for example, when a member is ill or in lack. A sense of cohesion and cooperation is a prime feature of these associations.

In the 1920s, kinship and communal unions sprang up in the main urban centers in Nigeria to promote the interests of their members. This became contact points for job opportunities. Membership of such associations provided safety net in time of crisis. Such rallied round when a person died to provide succor and carry the corpse home. Such were also known to contribute or loan money to send a member or child of a member overseas (Nnoli 1980).

The communalistic system is characterized by the principle of belongingness. The native expression that encapsulates this principle is the term Umunna. Literally, Umunna means children of the same father. However, the extension of the word transcends the nuclear family to include a similarity of heritage and lineage, historical, cultural, and traditional ties (Iroegbu 1996). Cardinal to the principle of belongingness is specific virtues such as group solidarity, commitment, hospitality, patriotism, and participation. The term "belonging" is not an abstract term but it finds expression in the commonness of land as it is both a common property and heritage of the entire community.

The solidarity sentiment predisposes one to see oneself in the other people living and working together, and identifying with other people's sorrows and joy. Mutual aid or assistance is the driving force. The solidarity sentiment is captured in such saying as aka nri kwo aka ikpa, aka ikpa akwo aka nri (the right hand washes the left hand and the left hand washes the right hand). This means that the individual requires the relationship of others and urges the individual to appreciate communal values such as cooperation and mutual aid. The right hand and the left hand complement each other and neither can wash itself clean without the other's assistance. The implication of this is that extreme individualism is not in the interest of the individual. Edet (2013) gives us examples of expressions of solidarity thus:

Practical expressions of the value of social solidarity were manifest in the custom of common sharing of meals, collective maintenance of public roads, markets, collective assistance to members who embark on major construction or reconstruction of their living quarters, collective discharge of burial rites and responsibilities, celebration of social occasions of happiness, and local festival. (Edet 2013, 244) 
Flowing from the foregoing, the overall atmosphere permeated by solidarity is one of acceptance, care, and concern for members as beings co-exist with other beings while at the same time perceiving themselves incapable of subsisting without the community.

\section{Communalism as a Theory of Justice}

This section highlights the essential ingredients of justice and how communalism can be regarded as a theory of justice. Subsequently, an attempt is made to examine the various spheres in which communalism as a theory of justice manifests.

In its distributive form, the term justice deals with how goods and services are shared among individuals. The core concept of justice is equality. From the perspective of equality, justice demands that the same amount of whatever we are sharing should be given to everyone if there is nothing relevant that distinguishes the possible recipients. Assorted reasons are advanced in favor of and against equality as a principle of justice. But the paper will not address these arguments.

Besides the principle of equality, another principle of justice is that of need. This requires the society to meet people's basic needs for food, clothing, and access to adequate medical care. The need principle can be served as a justification for not treating individuals equally.

Also, the principle of merit provides another reason for departing from the equality of treatment. This requires someone to have acted in a way that elicited some sort of treatment as a response. Under the merit principle of justice, a person may receive a favorable or unfavorable treatment depending on what the person has done. What the person deserves therefore, is a function of the actions or performances for which the individual is responsible. All these core elements of justice find expression in the communalist theory of justice.

Communalism, viewed from the perspective of justice, is compassion-based and to an extent right based. It tends towards the welfare of individuals regardless of whether they merit it or not by their own efforts. It covers among other things, such as social and economic access of everybody to food, clothing, housing, and other items of welfare. Besides, a person's rights, deserts, and needs are recognized as morally relevant to the question of how he should be treated. In case of needs, a person's needs are sometimes thought to give him sufficient justification for taking another man's property without his permission. For instance, a woman can pluck some palm fruits from the heap that somebody keeps by the road side to do her cooking without seeking the permission of the owner and the owner will not take offence.

Also, with respect to desert, it does appear that personal merit is recognized but not personal deserts. The society recognizes possession of certain qualities as meritorious but does not believe that merit should be honored or rewarded by the subject receiving benefit of any kind. In some parts of Igboland of south-east Nigeria, for example, merit is given a symbolic recognition. For instance, when a man has accumulated a large quantity of yam tubers from his cultivation and seeks to be crowned the king of yams, part of the quantity is taken away from him and distributed among members of the village leaving him with the title. What this means is that the meritorious man is recognized without implying that he deserves to keep all the benefits, which his efforts and abilities have brought to him. Indeed, consideration of the common good which is a requirement of justice, is more pronounced in this set-up than the market society that supplants it.

Besides meeting the basic needs of the individual, communalistic justice embodies the equality of treatment. Concretely, the principle of belongingness precludes the dichotomy thrown up by the relationship between the inferior and the superior, and the one engendered by class location could discriminate against the 
inferior regarding some social benefits that make for respectful human existence. The worst-off and the least privileged find space therein as their lot is improved by the community, which may be for all to feed and house themselves, to be cared for when sick, and to be educated. This may be interpreted as justice according to need as opposed to merit or desert.

Further, the communalistic system affords the individual room to enjoy liberty in the substantive sense by providing the conducive environment for full physical and moral development of persons. Substantive liberty in this sense includes the right and ability to participate in socio-communal life as well as has a share in the material wealth of the community. These two aspects of substantive liberty are enjoyed by all and sundry without discrimination. This is reflected in the right of the individual to have a say in the public affairs of the community and share in its social surplus. This guarantees the individual full membership of the community.

The principle of belonging and liberty enjoyed in the substantive sense help to nurture the good life and make life in the community worth living. Following them are the respect and solidarity, which accrue to the individual by virtue of his being a member of the community.

The individual has dignity, worth, and value and is esteemed in the eyes of the others due to respect. This is conferred on him because he is a person not because of the wealth or social status. It precludes discrimination based on class, sex, and inferior/superior relationship, which is a condition of justice.

The practice of liberty, which is political freedom, makes it possible for the individual to blossom given the basic necessities, which the system proffers. This has meaning only in the context of the community. Liberty here includes the satisfaction of personal needs and social needs and values. As Iroegbu (1996, 55) has rightly pointed out, these are necessarily limited and constitute the object of distributive justice. The point made here is that the community gives the individual the opportunity to develop his or her potentials by each being his or her brother's keeper helping those who are lacking economically to realize their aspirations. Subsequently, the paper looks at the following:

\subsection{Communalism and Leadership or Governance}

The system reflects political equality which is a shade of justice as equality. Following this, all forms of inequality are frowned at, especially those grant special privileges to people based on birth, sex, wealth, position, or class (Uduigwomen 2002). The individual participates in the government of his community either directly or indirectly and those who qualify by seniority, integrity, or recognizable achievement can vie for political positions. Leadership is provided by the Offo holders, the titled men and women (Uchendu 1965, 41). These did not rule alone, just as the abuse of office on the part of rulers is frowned at. Justice is manifested in the committee of elders that install and dethrone kings and the adjudication of disputes. The judicial actions of this committee act as checks on the power of the rulers (Dukor 2007, 60). The power of the rulers can be sustained in so far as they protect and serve the interest of the society.

Among the Igbo, the head of a family or the oldest member has a ritual staff known as Ofo. Ofo is a symbol of authority likened to the mace and it is respected as a jurist and intermediary between the family and its ancestors. The ritual staff is also a symbol of divine justice. Politically speaking, the family head or the holder of Ofo is the head of the committee, which considers disputes and gives advice on custom and tradition and indicates when a proposed action agrees with or violates them (Dukor 2007, 64 ). Further for Dukor (2007, 65), Ofo is not only a mystical experience among the Igbos but also a symbol of justice practically manifesting as authority, honesty, and truth. Ofo dispenses justice through judgment delivered by Ndichie, that is, the titled 
men who know customs and traditions as they relate to reality and truth. Ofo also dispenses judgment through judgment delivered in the court of the community deities. Similar to the western legal system, every side to a dispute is given fair hearing. Also, in that system, no one can be a judge in his own case.

\subsection{Communalism and Consensus in Decision-Making}

The political administration of the Igbo people of south-east Nigeria is a very good example of communalism as a theory of political justice. The philosophy of collective efforts and decentralization characterize the system. There is room for all and sundry to participate fully in taking decisions. Olisa (1971, 25) observes in this connection that the assembly of the whole town or village group is the highest platform for political decision and action. All adult males can attend and participate in the meetings of the town assembly. In such town assemblies, it is the titled elders that who preside over and deliberate over general discussions in a separate caucus and consultation called igba izu, and finally announce final decisions, which quite often win a general vocal approval of the people. Occasionally, when the final decisions of the elders are rejected, fresh efforts at winning consensus are resumed.

Uchendu $(1965,40)$ distinguishes two layers of political structure. These include the village and the village group. At the village level, the accepted practice is direct democracy in the similitude of Jean Rousseau's articulation. At the village group level, a representative system is adopted, and equality among the associating villages is maintained through the principle of "equal sharing of kola" and equal contribution of material resources needed for the survival of the group. Each village is autonomous and sovereign in most matters affecting it. The village is further segmented into a number of lineages and each lineage into major and minor lineages. Ejiofor $(1981,42)$ has affirmed in this connection that at the consultation, individuals could disagree and exchange vituperations, but once a consensus has been reached and well delivered, all opposition from within is silenced. In other words, an issue is discussed and deliberated upon until such a time an agreement is reached. Thus, the communalist system encourages political justice which is shown in the participation of the individual in the government of his community.

When one says that all adult males participate in village meetings, does it mean that there is no space for adult women? What picture does this scenario paint concerning gender equality as this pertains to political decision making? Views on these questions vary. For instance, Agbasiere (2000) asserts that traditionally, women do not have an active voice in purely political affairs... (That is) the privilege of final say in any decision concerning matters of common interest... What women possess according to her is a consultative voice, which can exert significant political influence, especially in matters that concern women directly. In other words, women's voice in the political space is not completely drowned. It is consultative rather than active. However, that of men is active. This in a way smacks of gender inequality.

Uchendu $(1995,58)$ rather makes the point that participation in the egalitarian traditional system of government is ensured through women's and men's associations, that is, a traditional dual sex political system, which obtained in pre-colonial Igbo society. This facilitated representations and consultations on issues for communal decisions. In this way, women's participation in community decisions was assured.

Highlighting this point further, Agara-Houessou-Adin $(1998,1 \mathrm{v})$ affirms that "Igbo women were at the forefront of political issues in Igboland prior to the incursion of the Europeans." According to her, "the dualsex political system... allowed women to carry out their responsibility without infringing on the others' territory. It was a highly developed form of democracy that existed, in that decisions were reached only after 
lengthy debates and persuasion either in the respective milieu or as a whole community" $(1998,289)$.

If the above is the case, how does one explain what appears as the silencing, exclusion, or the subordination of women as currently experienced? For instance, even in modern Igbo society, igba izu (consultation) is a strictly male affair. If men and women are invited to arbitrate in a matter, it is usually the men that who rise up to go and consult. Rose Uchem $(2001,36,38)$ has made the point that the subordination of women is not part of the original Igbo culture. She attributes this to the introduction of women's inferiorization through western Christianity and colonial policies in Nigeria. If women's activism as portrayed by the women's war of 1929 is anything to go by, Uchem's position in this regard has a lot of merit.

\subsection{Communalism and Moral Rules}

Ethics, religion, and the supernatural are integrated in the formulation and application of justice as this pertains to moral codes. The mores and customs of the people are morals and are blind when it comes to punishing their violations. This implies that infringements on such are punished irrespective of the person's background, social achievement, and wealth. In his Things Fall Apart, Chinua Achebe (1959, 128-9) gives us an insight into this: During a funeral, the dead man's 16-year-old son was killed by the explosion of Okonkwo's faulty gun. Although what happened was an accident, Okonkwo, the main character of the book, was to flee the village and remained in exile for seven years. "It was a crime against the earth goddess to kill a clansman and a man who committed it must flee from the land."

Okonkwo went into exile irrespective of all his social achievements and the honor he had brought to his village through his wrestling contests. This is a clear demonstration of communalistic justice at work. Right from the cradle, the children are socialized through various means to know and respect societal values and moral rules, which include acceptance of the fact that community is more important than the individual, justice, social harmony as well as order and unity, hospitality, lack of duplicity, honesty, and cooperation (Ilogu 1974, 131). These implicitly teach the tolerance also as captured in a common saying among the Igbos: egbe bere, ugo bere, nke si ibe ya ebena, nku kwa ya (Let the kite perch and let the eagle perch, which ever says the other will not perch, let its wings break). This emphasizes the principle of "live and let live" (onyebiri onyebiri). All these create a conducive surrounding for justice to thrive.

\subsection{Communalism and Punishment}

Punishment, whether capital or not is anchored on the violations of the norms of society. As already noted, an individual in the traditional Igbo African society has fairly defined rights and duties. Due to the feeling of brotherhood for one another, any act of wrong doing by an individual is taken seriously. It is seen not as an individual affair but a group thing in terms of its consequences. T. U. Nwala has succinctly made the point in this connection that "a community can be made to suffer because of the bad conduct of one of its members; therefore each person's conduct is the responsibility of the whole community" $(1985,148)$. Achebe $(1959,32)$ alludes to this fact. Okonkwo beat up his third wife during the week of peace. This horrified his neighbors and the priest of Ani who came to rebuke him: "You have committed a great evil... The evil you have done can ruin the whole clan. The earth goddess whom you have insulted may refuse to give us increase."

The above is the function of the African metaphysics that there is unity and interconnectedness of things as well as an ordered relationship among all beings in the universe. Flowing from the ontological relationship which is believed to exist among beings, any undesirable act is viewed to bring disorder in this order and hence 
and affect the other beings. Placide Tempels $(1959,60)$ corroborated this view when he wrote that "the world of forces is held like a spider's web of which no single thread can be caused to vibrate without shaking the whole network."

It is in the above connection that crime is seen as the upsetting of the cosmic balance and a disruption of the ontological order. Thus, following any breach of morals or custom, sanctions are imposed and the infringement of the customs is punished through that means. These sanctions are believed to be imposed by the deities and ancestors through such disasters like death, epidemics, droughts, famine, accidents, and other natural disasters. In some cases, such is imposed by the community by selling the undesirable elements into slavery or banishment.

The taboos, which F. U. Okafor $(1984,162)$ describes as the "criminal code of the so called civilized societies," include incest, murder, and theft. These were seriously considered to be out of tune with the accepted code of conduct and consequently punishable by the community. In the case of murder, the murderer is made to pay with his own life for that there is an Igbo adage that says "anaghi agwa onye gburu mmadu na gwala Ọchu," meaning that a murderer is not informed that restitution has been made for his deed. Regarding other levels of contravention, propitiatory offering or sacrifice is made to restore the balance and absolve the offender. Specifically, Okafor $(1984,162)$ asserts that "the ritual ceremony performed usually after each breach of the divine law is intended to wipe away the stain of the odious crime, appease the spiritual forces, and restore the ontological order believed to have been disrupted by the breach."

Though punishment may have a deterrent or utilitarian intent, this is not the major characteristic. It is seen as a means of restoring the ontological order which has been disrupted by an antisocial act. Unlike in the modern times when liability in terms of punishment is solely an individual affair, the traditional Igbo African setting considers punishment not only as an individual but also as a group or community affair as the case may be. The concern of justice following this is to restore the ontological balance.

\subsection{Communalism and Equitable Distribution of Resources}

The social formation of the traditional African society is characterized predominantly by communal mode of production. The unit of social organization is the clan, while the unit of social production is the family's (Onimode 1982, 11). Land and labor are the major means of production and they are owned jointly by all the social groups. The land is managed by the chief and individual families even though communally owned. These means of production do not promote private property but communal property "governed by complex regulations emphasizing social responsibility" (Onimode 1982, 11). The family, not the individual is the unit for the ownership of land. "This non-differentiation in allocation of commonly owned property is an important economic value translated into a display of distributive justice" (Ajei 2007, 221).

The individual under this system has fairly defined rights and duties within his group. A close look at the rights of the individual in relation to the product of the soil cultivated by family group or the catch accruing from cooperative fishing discloses that he is not a person without claims upon or mutual obligations towards other members of the group. The proceeds of the common effort in most cases are shared among participants according to individual deserts or as mutually agreed by the group. In the event of social surplus, such surplus is saved for emergency, e.g., war. If the products are sold, all those who have contributed will get a share from the sale of the products.

Thus, "mutual help, cooperative production, and obligation to the group governed production relations" 
(Onimode 1982, 11). It is worth noting at this point that even in the event of limited amount of social surplus accruing from the appropriation of nature, there is no disproportionate appropriation. This means that the system has a sense of justice in terms of proportion. This is the basis of the people's social relationship, their ontology, and the feeling of brotherhood.

\section{Communalism and the Human Person}

It can be argued from the foregoing that the human person is not submerged in the community as some writers have said. The reason is that the interaction is not one way as it is beneficial to both the individual and the community as this pertains to the development of the individual's personality and the wellbeing of the community. The individual has certain rights which he enjoys at the hand of the community. He also has obligations toward the community. Right from childhood, the individual is taught to appreciate his/her obligation to the members of the group, to think about and act for the survival of the group and not to indulge in any act that would disrupt the ontological equilibrium of the community such as incest, murder, etc or commit any act perceived as aru (abomination).

It is in the above connection that the Ghanaian philosopher, Kwame Gyekye (1988, 31-32) affirms that there is an interaction between the individual and the community to the extent where the community does not necessarily crush the individual's identity and creativity. The individual possesses a clear idea of himself as a distinct person of volition. What this means in other words, is that there is a mean that avoids the excesses of extreme individualism and suffocating communalism. This implies that the individual enjoys autonomy which enables him to make choices regarding his goals, and how to pursue those goals and control his destiny. This does not in any way mean separation from the norms and standards of the communalist system or does imply demanding an anarchistic environment.

Gyekye makes the point further that the individual may even want to question and reevaluate some aspects of the communalistic arrangement as unappealing. This is a function of his autonomy as an individual in spite of the fact of his being socialized by the community. According to him, "The reevaluation may result in the individual's affirming or striving to amend or refine existing communal goals, values, and practices; ... it means also that the communal structure cannot foreclose the reality and meaningfulness of self assertiveness that the individual demonstrates in her actions" (Gyekye 1997, 54).

Furthermore, there is corporate responsibility from individual to individual, from individual to group and from group to group. Although the individual exercises considerable independence, such autonomy or the freedom does not amount to license but is constricted to the extent to which it can become detrimental to societal aspirations and wellbeing.

The land tenure system guarantees access to land to all. There is equitable distribution of collective wealth. This is at variance with current trends in contemporary society in which those who find themselves in power appropriate public wealth. The obvious consequences of the graft characterizing the rulers are found in the abject poverty, starvation and lack, which have been the experience of the majority of the people. Attempts must be made to universalize these traditional values and make them constituent parts of social policy measures aimed at developing the individual human person.

The community provides a non-hostile environment within which the individual strives to achieve his/her goals in life. The cooperation and sympathy of others then are sine qua non for social human existence. From this point of view, it is the community which enables the self realization of the individual, whose ability to act 
freely as a moral agent is not impeded in any way by being naturally social. Accordingly, the central tenet of African communitarian ethics is that one cannot realize ones full potential in life in isolation. This is not life diminishing, rather it is life enhancing from the individual viewpoint.

If solidarity and cooperation are necessary requirements for human living and flourishing, then that it behooves of the individual to take heed of the effects one's activities may have on the welfare and interest of others. One's conduct, preferably, should contribute to the common good because it is from this pool of good that one's own welfare can be extracted.

In view of the above dynamics of the communalistic society, one does not however, see how the individual disappears in the web of social relationships or how his ethical identity is wholly dissolved by the community as some writers have tried to argue. Ajei $(2007,201)$ has affirmed in this connection that individuals are responsible for the course of their lives, and that individual effort is necessary for the fulfillment of needs and achievement of goals. Ample room is provided for individualist values and talents in the communalist structure. Gyekye $(1996,35)$ underscores this point in his position that "African communal system, however, does not exclude individualistic values." He elaborates his views in the following terms:

The interaction between the individual and the community (or group) is therefore, considered basic to the development of the individual's personality as well as to the overall success of and wellbeing of the community.... To strike a balance in this connection is to recognize the claims of bothcommunality and individuality; it is to try to integrate individual desires and social ideals and demands. $(1996,50)$

This means that "private property, such as cattle existed side by side with communal property, such as land" (Molema 1920, 115).

What resonates following the foregoing is that the individual under communalism enjoys substantive justice. He enjoys political or civil justice as this pertains to the running of the community. He also enjoys socio-economic justice which makes it possible for him to benefit from the material wealth of the community. When all these are put together, it can be argued that such an individual experiences civil and socio-economic justice in a practical way. This stands opposed to the paper rights, which many national constitutions in Africa contain and majority of the citizens do not actually enjoy in a fundamental sense due to winner takes all attitude of the majority of the elites who occupy public offices.

\section{Dilution of Communalist Values and the Contemporary Society}

Given all that have been said concerning the dynamics of the traditional communal society, certain fundamental values of that society can be pinned down. These include collective responsibility, support from the family, and psychological fulfillment derived immensely from the community. The affinity that exists amongst persons in that society has an advantage, which issues from the moral force on the traditional society in which everyone can be nurtured as people belonging to the same family.

But cultural changes have occurred consequent upon the influence of colonialism. The result of this is that the somewhat worked out balance in production and fairly equitable distribution and consumption of resources during the pre-colonial era have been dislodged. Also, traditional systems of social protection and control have been undermined. Consequently, the individual is severed from the usual social ties and relations of interdependence and reciprocity. The individual has become more concerned with maximization of profit unmindful of community obligations. Alienation has set in as one of the formidable social ills in Africa. Alienation (estrangement) has several meanings. For Gwynn Nettler $(1957,672)$, an alienated person is "one 
who has been estranged from and made unfriendly toward, his society and the culture it carries." This is the sense in which alienation is used in this paper. Other social ills that have emerged include poverty, crime, unemployment, division of the society into "haves" and "have nots," and social disorganization. Further, the mobility from subsistence to exchange economy, urbanization, and the trend towards wage employment has had a devastating effect on the social and economic life of Africans.

James Coleman $(1986,80)$ alludes to the consequences of the above in his view that "these revolutionary changes profoundly affected traditional loyalties, patterns of behavior, and social obligations. They also created tensions and embitters economic insecurity as well as individualistic and materialistic attitude and values." Kwasi Wiredu (1996) throws more light on the effect of this erosion in his view that this circumstance is in which the individual is left on his own to draw out his own life span and thereby shown lack of responsiveness to public opinion.

The ensuing alienation has manifested in assorted ways in contemporary Africa, namely, violence, armed robbery, kidnapping, and economic sabotage (vandalization of electric power installations as well as oil pipe lines). Hallowed traditional values such as the respect for the human person, honesty, and integrity, which supports or oils the wheel of communalism, have been thrown overboard with the result that crimes considered abominable within that framework are perpetrated with impunity.

Following the above, many individuals have lost the sense of community and now find themselves isolated to do whatever gratifies their whims at the expense of the community. There have been incidents where wives and young people fake their own kidnapping in order to extort money from their spouses and parents. Human trafficking (including children and women) as well as killing for ritual purposes has become the order of the day. John S. Mbiti (1969) highlights this saying: "Amidst the people who live in cities, the individual discovers that he is alone. The masses around are both blind and deaf to him, and they are indifferent and do not care about him as a person."

When viewed from the perspective of government, this neglect can be used to explain the endemic corruption in Nigeria and lack of patriotism on the part of many individuals. Over the years, retired public officials find themselves abandoned by the very society that they spent their productive years serving for. Some die without receiving their gratuity and other entitlements, while others are owed pension for months on end. There are yet others who die in road mishaps in an attempt to travel long distances on terribly bad roads in order to collect their pensions. Several years back, the Nigerian Television authority (NTA) exposed the plight of retired Nigerian soldiers regarding the issues raised here. The apparent way out for many is the corrupt enrichment while in public office in order to prepare for their old age. This amounts to a vote of no confidence in the society. This is aptly captured by Julius Nyerere. According to him:

Apart from anti-social effects of the accumulation of personal wealth and the very desire to accumulate, it must be interpreted as a vote of "no confidence" in the social system. When a society is so organized that it cares about its individuals, then, provided he is willing to work, no individual in that society should worry about what will happen to him tomorrow if he does not hoard wealth today. Society itself should look after him or his orphans. This is exactly what traditional African society succeeds in doing. $(1974,3)$

The communalist ideology embodies some elements of justice, which demands a constant effort to recognize and maintain an equitable balance in the sharing of resources in society as a means of keeping the component parts of society. It presupposes a fair mode of sharing and distribution of benefits and burdens within the society (Ekei 2006, 168). One thing this aspect of justice highlights is that there is an obligation on 
the part of governments that societal wealth is for everybody not just a few and that government indeed fails in its responsibility not in using the societal wealth in developing and empowering human beings. In the traditional communalist framework, wealth was seen as being in the service of community rather than the benefit of the individuals.

This communalist ethic is incongruent with the winner who takes all philosophy of African politicians and rulers. This philosophy focuses on the self and accounts for corrupt enrichment. Pursued to its logical conclusion, the development of social infrastructure and promoting people centered development that cater for human needs are compromised. With the kind of massive looting which has become the albatross of most African nations, social policy objectives are not met and where these are met, they are met only partially.

Highlighting the concept of justice from four perspectives, namely, justice as co-existence, justice as acceptance, justice as caring, and justice as concern, Ekei $(2001,2)$ projects belonging as an attribute of right. This entails that the associates have mutual expectations of right and obligations from one another (Ekei 2006, 170). Essentially, all the participants are co-owners of the gifts of nature in the area of their residence. As he put it, "Every gift of nature belongs by right to all who belong within the community or state, housing the gifts" (Ekei 2006, 170). This will include mineral resources such as oil, diamond, gold, or copper. The reason for entitlement is belongingness of individuals. By reason of this logic, everyone including the handicapped and the destitute has their legitimate dues from their community out of moral justice and not out of charity.

In contemporary African society, land finds its parallel in the natural resources available to contemporary African states in form of oil, copper, diamond, and so on. The prevailing trend whereby that national resources are taken for plunder by public office holders is against the spirit of communitarian justice for it fritters away resources meant for development, both human and material. The communitarian doctrine will ensure that laws governing ownership of natural resources are revised as their main aim is the human and economic rights of citizens (Ajei 2007, 221).

\section{Conclusion}

This paper sets out to examine the praxis of communalism with a view to show how its principles of care and fellow feeling can be used to address the problem of alienation from society characterizing many individuals in Africa. In pursuance of the main objective of this paper, efforts have been made to discuss the dynamics of the communalistic society and that what has emerged is that the individual has a sense of belonging and solidarity, which predisposes him toward the other. The community carries the individual along while at the same time the individual has a sense of obligation towards the community by eschewing acts that would be detrimental to community-individual relationship. Furthermore, the paper has used issues such as leadership/governance, consensus in decision, punishment, and equitable distribution of resources for the purpose of illustrating communalism as a theory of justice. It has also tried to show that the individual has rights which are upheld by the community and that both the community and the individual human person benefit in a relationship that is mutually enhancing. Given the advent of colonialism, the traditional values have suffered a dislocation. The consequence is that the hitherto close affinity that exists has been adversely affected. The individual is now left alone to fend for himself.

From the results of the investigation, this paper affirms that making and implementing the principles discussed herein will enable governments in Africa to address the assorted social problems and crises that appear to be their challenge in the 21 st century. 


\section{Works Cited}

Adin, Agara-Houessou. The Concept of Sitting on A man: Igbo Women and Political Strategies (Nigeria). Doctoral Dissertation, Tempel University 1998. Dissertation Abstract International, 59, 3925.

Agbasiere, Joseph Theresa. Women in Igbo Life and Thought. NY: Routeledge, 2000.

Ajei, Martin Odei. Africa's Development: The Imperatives of Indigenous Knowledge and Values. Unpublished doctoral dissertation, University of South Africa, 2007.

Aristotle. The Politics. Trans. T. A. Sinclair. NY: Penguin Books Ltd, 1962.

Asouzu Innocent. Ibuanyidanda: New Complementary Ontology. Zurich: LIT Verlag GmbH \& Co. KG Wien, 2007.

Coleman James. Nigeria: Background to Nationalism. Benin City: Brobury \& Wistrom, 1986,

De Jouvenal Bertrand. Sovereignty: An Inquiry into the Political Good. Cambridge: University Press, 1957.

Dukor, Maduabuchi. "The Concept of Justice in African Philosophy." Ike Odimegwu, ed. Perspectives on African Communalism. Oxford: Trafford Publishing, 2007. 54-72.

Edet Mesembe. African Philosophy of Values (Afroxiology) from the Perspective of Ibuanyidanda Philosophy. Unpublished doctoral dissertation, University of Calabar, 2013.

Ejiofor, Lambert. Dynamics of Igbo Democracy: A Behavioral Analysis of Igbo Politics in Aguiyi Clan. Ibadan: University Press, 1981.

Ekei, John Chukwuemeka. "Justice in communalism: A foundation of Ethics." African Philosophy. Lagos: Realms Communications, 2001. 2-13.

Ekei, John Chukwuemeka. "Justice in communalism and Social Stability in Philosophy and Praxis in Africa." Martin Asiegbu and Joseph A. Agbakoba, ed. Ibadan: Hope Publishers, 2006. 167-75.

Gyekye Kwame. African Cultural Values: An Introduction. Philadelphia. Pa: Sankofa Publishing Company, 1966.

Gyekye Kwame. Tradition and Modernity: Philosophical Reflections on the African Experience. Oxford: Oxford University Press, 1997.

Igwe Agbafor. Zik: the Philosopher of Our Time. Enugu-Nigeria: Fourth Dimension Publishing Co., Ltd, 1992.

Iroegbu Pantaleon. The Kpim of Politics: toward Justice in Africa. Owerri-Nigeria: International University Press, 1996.

Ilogu Edmund. Christianity and Igbo Culture. NY: Nok Publishers, Ltd., 1974.

Mbiti, John. African Religion and Philosophy. London: Heinemann, 1969.

Molema, Silas Modiri. The Bantu: Past and Present. Edinburgh: W. Green and Sons Ltd, 1920.

Nnoli Okwudiba. Ethnic Politics in Nigeria. Enugu-Nigeria: Fourth Dimension Publishing Co. Ltd., 1980.

Nze, Chukwuemeka. Aspects of African Communalism. Onitsha: Veritas Publishers, 1989.

Nyerere Julius. Ujamaa: Essays on Socialism. Eastern Africa: Oxford University Press, 1974.

Nettler Gwynn. “A Measure of Alienation.” American Sociological Review 22 (1957): 670-7.

Nwala, Timothy. Igbo Philosophy. Nigeria: Lantern Books, 1985.

Odimegwu, Ike. "How Communalist is Africa? Philosophy Praxis." Journal of the Nigerian Philosophical Association, Vol. $3,2007$.

Okafor, Fidelis. "Legal Positivism and the African Legal tradition.” International Philosophical Quarterly, Vol. XXIV, No. 2, No. 94 (June 1984).

Olisa Micheal. "Political Culture and Stability in Igbo society." M. J. C. Echerue \& S. O. Anozie ed. Igbo Traditional Life, Culture and Literature. The Conch, Vol. III, 2 (1971).

Onimode Bade. Imperialism, Underdevelopment in Nigeria: the Dialectics of Mass Poverty. London: Zed Press, 1982.

Ruch, E. A., Omi \& K. C. Anyanwu. African Philosophy: An Introduction to the Main Philosophical Trends in Contemporary Africa. Rome: Catholic book Agency, 1984.

Tempels, Placide. Bantu Philosophy. Paris: Presence Africaine, 1959.

Uchem Rose. Overcoming Women's Subordination in the Igbo African Culture the Catholic Church: Envisioning an Inclusive Theology with Reference to Women. Parkland: Dissertation.com, 2001.

Uchendu, Victor. The Igbo of Eoutheast Nigeria. NY: Holt, Rinehart, and Winston, 1965.

Uchendu, Patrick. Education and the Changing Economic Role of Nigerian Women. Enugu: Fourth Dimension, Publishing, 1995.

Uduigwomen, Andrew. “African Communalism: Individual Freedom Versus Communal Demands.” Sophia: An African Journal of Philosophy, Vol. 4, 1 (2002).

Wingo, Ajume. "Fellowship Associations as Foundation for Liberal Democracy in Africa." Kwasi Wiredu ed. A Companion to African Philosophy. Oxford: Blackwell Publishing Ltd, 2004. 450-9.

Wiredu, Kwesi. Cultural Universals and Particulars: An African Perspective. Bloomington: Indiana University, 1996. 